\title{
Kortere studietider - krav og konsekvenser
}

\author{
Palle Rasmussen, professor, Institut for Laring og Filosofi, \\ Aalborg Universitet.
}

De lange studietider ved universitetsuddannelserne er et tilbagekommende tema i uddannelsespolitikken. I begge de store samfundsøkonomiske planer, som den daværende regering og opposition fremlagde i 2010, foreslås tiltag til afkortning af studietiderne. Men faktisk er der i de seneste år blevet indfort en række tiltag, herunder stramme rammer for specialeskrivningen og frrdiggørelsesbonus. Virkningerne af disse tiltag kendes endnu ikke. Det gxlder også mulige utilsigtede konsekvenser, som for eksempel underminering af de studerendes faglige kompetencer og marginalisering af studerende med svagere forudsætninger og netværk. I artiklen argumenteres der for, at det $i$ denne situation vil være uforsvarligt at indføre yderligere foranstaltninger til forkortelse af studietiderne.

\section{Studietider i de samfundsøkonomiske planer}

Lange studietider ved universitetsuddannelserne har gennem lang tid været et uddannelsespolitisk tema, som dukkede op med jævne mellemrum. Inden for de seneste år er der dog kommet stærkere politisk fokus på spørgsmålet. I 2010 fremkom to store planer for at sikre det danske samfund og dets økonomiske grundlag i de kommende år, Danmark 2020, som er fremlagt af den daværende regering bestående af Venstre og Konservative, og Fair Løsning, som er fremlagt af Socialdemokratiet og SF. Uddannelse står centralt i begge planer, og begge foreslår også tiltag til at afkorte studietiderne.

I Danmark 2020, som Regeringen fremlagde i foråret 2010, opstilles ti mål for det danske samfund af 2020. To af disse mål handler klart om uddannelse, nemlig at danske skolebørn skal være blandt de dygtigste i verden (nr. 3), og at mindst et dansk universitet skal være blandt Europas top 10 (nr. 4). De videregående uddannelser indgår imidlertid også under målet om, at det danske arbejdsudbud skal være blandt de 10 højeste i verden (nr. 2). Til at opnå dette mål opregnes en række initiativer, blandt andet tidligere færdiggørelse af uddannelser. Det uddybes således:

"Regeringen vil vurdere mulighederne for at justere SU-systemet, så de studerende tilskyndes til at færdiggøre deres uddannelser tidligere. Regeringen vil samtidig evaluere de foreløbige erfaringer med den nye ordning, hvor der 
beregnes en forhøjet karakter fra den adgangsgivende eksamen, når videregående uddannelse påbegyndes inden for to år fra den adgangsgivende eksamen." (Regeringen, 2010, s. 17).

Dette initiativ blev konkretiseret i et regeringsudspil i efteråret 2010 (Regeringen, 2010a), som indebar fjernelse af SU for hjemmeboende unge på ungdomsuddannelserne (de såkaldte "cafepenge"), begrænsning af SU til uddannelsernes normerede tid, bonus til unge som påbegynder uddannelse og færdiggør på under normeret tid, samt fremrykning af 1,08-reglen til at gælde unge, som påbegynder videregående uddannelse inden for et år efter afslutningen af den adgangsgivende uddannelse. Regeringen forventer, at gennemførelse af udspillet vil øge udbuddet af arbejdskraft med ca. 4.000 personer og styrke de offentlige finanser med cirka 1 milliard kroner. Heraf vil besparelser på SU-udgifterne udgøre 250 millioner, mens de resterende 750 millioner vil være resultat af, at de studerende kommer hurtigere ud på arbejdsmarkedet.

Planen Fair Løsning blev oprindeligt fremlagt af Socialdemokratiet og SF i sommeren 2010. Et år senere fremkom der en ny udgave, som var revideret og udbygget som reaktion på debatten om den oprindelige plan samt regeringens 2020-plan. Også i Fair Løsning står uddannelse centralt. I den oprindelige udgave var der opstillet fem initiativer, og et af dem hed "Mere og hurtigere uddannelse" (Socialdemokratiet \& SF 2010, s. 7). Her blev der opstillet et mål om, at danske unge skulle gennemføre en kompetencegivende uddannelse et halvt år tidligere i gennemsnit. I den reviderede udgave af planen er strukturen lidt anderledes, men hurtigere gennemførelse af uddannelse er stadig et væsentligt element. I afsnittet om uddannelsespolitik hedder det: "Socialdemokraterne og SF har et mål om, at unge skal et halvt år hurtigere igennem deres uddannelse", og der henvises blandt andet til følgende konkrete initiativer for at nå dette mål: Omlægning af optagelsessystemet, så det bliver lettere at blive optaget på drømmeuddannelsen, hvis man starter lige efter endt ungdomsuddannelse; fremrykning af 1,08-modellen fra 2 til 1 år; fjerne barrierer for hurtigere gennemførelse, fx ved at have optag flere gange årligt samt afskaffe værnepligten; kontant bonus ved færdiggørelse af kandidatuddannelse på normeret tid; bedre tilrettelæggelse af videregående uddannelser, så den studerende kan lære mere på samme tid, fx ved at have tre semestre på et år eller et "hurtigt spor" (Socialdemokratiet \& SF, 2011, s. 66).

Realiseringen af målet om at få de unge hurtigere igennem uddannelsessystemet forventes at give en samfundsøkonomisk gevinst på 2,3 mia. kr. 
Som bekendt skiftede den parlamentariske magtbalance ved folketingsvalget i september 2011. Den nye regering, som i skrivende stund endnu ikke er dannet, vil hvile på et skrøbeligt flertal og få store vanskeligheder ved at realisere Fair Løsning. I forhold til spørgsmålet om studietider ved universitetsuddannelserne har det næppe den store betydning; for som det fremgår, er der en høj grad af overensstemmelse mellem de to parlamentariske blokke på dette område. Den væsentligste forskel er, at planen fra $\mathrm{S}$ og SF er mere ambitiøs med målet om at nedbringe studietiderne med et halvt år i gennemsnit.

\section{Konkurrencestatens økonomiske rationaler}

De samfundsøkonomiske planer og deres uddannelsespolitiske forslag må ses i sammenhæng med den tendens i dansk politik, som er blevet kaldt en udvikling mod konkurrencestaten (Pedersen, 2011). Det er i høj grad en reaktion på de sidste par årtiers stigende globalisering og kom blandt andet til udtryk i Globaliseringsrådets arbejde i årene 2005-2006. Her formulerede en samling af stærke politiske og økonomiske aktører det synspunkt, at den intensiverede globale konkurrence kræver omstillinger af det danske velfærdssamfund med henblik på at sikre både institutionernes og individernes bidrag til at fremme vækst og velstand. Konkurrencestatens politik går ud på at styrke nationens institutionelle konkurrenceevne, blandt andet ved at opbygge stærke samspil mellem offentlige og private institutioner, men især ved at sørge for, at samfundsmedlemmerne er mest muligt effektive, produktive og innovative. Derfor kommer uddannelse til at stå centralt, men på en ny måde. I den tidligere velfærdspolitik, som var udviklet siden 1930'erne med Socialdemokratiet som ledende kraft, blev uddannelse set som et velfærdsgode, som flest muligt borgere skulle have ret til og kunne bruge til at forbedre deres levestandard og livskvalitet. I konkurrencestatens politik er velfærdsrettighederne vel ikke forladt, men de er suppleret med en forpligtelse til at bruge uddannelsesmulighederne produktivt og effektivt, således at uddannelsesinvesteringerne bidrager mest muligt til den nationale konkurrenceevne, som skal give mulighed for velfærd. Der sker således en delvis forskydning fra ret til pligt i borgernes adgang til uddannelse.

I begge de samfundsøkonomiske planer betragtes uddannelse ud fra to økonomiske logikker:

På den ene side ses uddannelse, især videregående uddannelse, som en samfundsmæssig investering. Sammenligner man personer med og uden uddannelse, har de uddannede stærkere tilknytning til arbejdsmarkedet og er mere produktive. Og uddannelsens positive økonomiske virkning er stærkest for personer med videregående uddannelse. Videregående uddannelser med godt og relevant fagligt indhold gør de uddannede mere vidende, fleksible og innovative, og derfor kan de medvirke til at 
forbedre det danske samfunds konkurrenceevne (Lundvall, 2001; Junge \& Skaksen, 2010).

På den anden side indebærer selve uddannelsestiden omkostninger for det offentlige. De studerende forbruger offentlige uddannelsesressourcer, deres leveomkostninger dækkes overvejende af staten via SU-systemet, de indgår ikke meget i arbejdsudbuddet, og de bidrager i minimalt omfang til statens skatteindtægt.

Begge disse logikker er reelle, og de politiske planer må tage højde for dem. Men den måde, hvorpå begge politiske blokke går til spørgsmålet om studietider, er af flere grunde problematisk.

Der indgår tilsyneladende ikke overvejelser om de potentielle modsætninger mellem de to logikker. Hvis rammerne for universitetsuddannelserne strammes for meget af hensyn til at begrænse samfundets direkte omkostninger, kan uddannelserne ikke nødvendigvis blive ved med at give de uddannede den viden, de færdigheder og de kompetencer, der sikrer de uddannedes positive bidrag til konkurrenceevnen. Hvor grænsen går, er svært at sige, og universitetsuddannelserne har ofte vist sig at kunne opretholde høj uddannelseskvalitet under vanskelige vilkår. Men at forkorte studietiderne med gennemsnitligt et halvt år, som oppositionen lægger op til, vil kræve stærke indgreb i rammerne.

Et af de forhold, som kravet om at begrænse studietiderne ikke tager højde for, er de studerendes tilknytning til og overgang til arbejdsmarkedet. Ligesom studerende andre steder i verden supplerer danske universitetsstuderende deres indkomst med erhvervsarbejde i fritiden. En del af dette arbejde er ufaglært, ofte i servicesektoren. En anden del rummer arbejdsopgaver, som kan have indholdsmæssig relevans for de studerendes uddannelse, for eksempel hvis de arbejder som medhjælp i vidensorganisationer eller virksomheder. For mange studerende giver dette studierelevante erhvervsarbejde både kompetencer og netværk, som kan sikre dem jobs efter endt uddannelse. Det er en velkendt mekanisme, som bl.a. blev bekræftet for nogle år siden i en undersøgelse initieret af Videnskabsministeriet (Ministeriet for Videnskab, Teknologi og Udvikling 2005). Videnskabsminister Helge Sander udtalte dengang: "At få brugt sin viden i praksis og knytte kontakter i relevante erhvervsmiljøer er motiverende og skaber god sammenhæng mellem studierne og de fremtidige beskæftigelsesmuligheder". (Pressemeddelelse, 5. januar 2005). Men presset for at begrænse studietiden kan gøre det sværere for studerende at fastholde det studierelevante erhvervsarbejde. Det gælder ikke mindst i uddannelsens afsluttende fase, hvor rammerne for specialeskrivningen vil tvinge de fleste studerende til at nedprioritere erhvervsarbejdet, selv om det måske kunne give adgang til job efter eksamen. 
De tiltag, der foreslås i de samfundsøkonomiske planer, har alt for lidt sammenhæng med virkeligheden i uddannelserne og på arbejdsmarkedet. Sådanne indgreb er der allerede kommet en del af de senere år, og deres virkninger er vanskelige at overskue.

\section{ÆEndringer i rammerne for studieforløb}

I de senere år er der blevet gennemført en række ændringer i rammerne for universitetsuddannelserne med henblik på at effektivisere studieforløbene. Jeg vil især fremhæve følgende: Med velfærdsaftalen fra 2006, som blev tiltrådt af et bredt flertal i Folketinget, blev fortrinsretsordningen (1,08-ordningen) indført. Ordningen betyder, at ansøgere til de videregående uddannelser siden optaget 2009 har fået deres adgangskvotient forhøjet med en faktor pa 1,08, hvis de søgte ind inden for to år efter den adgangsgivende eksamen. Formålet med 1,08-ordningen er at tilskynde de unge til at påbegynde en videregående uddannelse hurtigere efter den adgangsgivende eksamen.

Året før, i 2005, var kvote 2 ved optaget til universitetsuddannelsernes blevet omlagt som led i revision af adgangsbekendtgørelsen i 2005. Ud fra den vurdering, at for mange unge brugte lang tid på at samle point til kvote 2, blev kvoten gjort mindre, så der som hovedregel optages 10 procent via kvote 2 og 90 procent via kvote 1 på universitetsuddannelserne.

Velfærdsaftalen fra 2006 indførte også bindende tidsbegrænsninger for kandidatspecialer. Historisk har studerende ofte brugt mere end det normerede halve år på specialet, og formålet med den nye ordning var at fjerne denne årsag til studietidsforlængelser. Ordningen betyder, at den studerende bruger et eksamensforsøg, hvis specialet ikke afleveres inden for den aftalte tidsfrist på normalt et halvt år. Der aftales en ny opgaveformulering, der skal ligge inden for samme emneområde med en afleveringsfrist på tre måneder, og den studerende bruger det næste eksamensforsøg, hvis der heller ikke i denne omgang afleveres.

I 2009 blev der indført færdiggørelsesbonus ved universiteternes kandidatuddannelser. Bonus udløses til det enkelte universitet for studerende, som gennemfører kandidatuddannelsen inden for normeret tid plus tre måneder. Det samlede beløb til færdiggørelsesbonus er et fast beløb, der fordeles mellem universiteterne forholdsmæssigt efter antallet af rettidige afsluttere.

Det er svært at vurdere, hvilke virkninger disse tiltag har haft. Data om optaget til de videregående uddannelse i 2010 pegede ikke på nogen tydelig virkning af 1,08 bonusordningen; de nyoptagne studerende er blevet yngre, men det fortsætter blot en 
udvikling, som har været i gang de sidste 10 år (Politiken, 4. august 2010; "Karakterbonus har begrænset effekt"). Ordningen med tidsbegrænsning for universitetsspecialer har eksisteret så længe, at virkninger burde kunne spores, men eksisterende statistik (Undervisnings- og Bygningsstyrelsen, 2011) giver ikke mulighed for det.

Oplysninger om hvor mange afsluttende studerende, som hvert år udløser færdiggørelsesbonus, er tilgængelige. Ordningen har kun eksisteret $i$ to år, og som forventeligt viser tallene ikke nogen forandring i denne korte periode. I 2010 var det 36 pct. af de afsluttende kandidater, som udløste bonus. Dette dækker dog over store forskelle mellem hovedområder og institutioner. Inden for Humaniora var andelen af bonuskandidater 21 pct. mens den inden for Sundhedsvidenskab var 57 pct. Færdiggørelsesbonus forstærker altså de eksisterende skævheder i tildelingen af ressourcer til hovedområderne. Der er også stor forskel mellem universiteterne: Ved Københavns Universitet var andelen af humanistiske bonuskandidater 9 pct., mens den ved Aalborg Universitet var 64 pct. (beregnet efter oplysninger i Universiteternes Statistiske Beredskab, ark F, Danske Universiteters hjemmeside).

Ud fra min erfaring fra uddannelserne ved Aalborg Universitet kan jeg imidlertid nævne nogle eksempler på uheldige eller uhensigtsmæssige konsekvenser af de indførte tiltag.

Ved en række uddannelser er der tradition for, at specialestudiet afsluttes med en mundtlig eksamen på grundlag af den afleverede specialerapport. Det gælder blandt andet uddannelserne ved Aalborg Universitet. Der er mange gode argumenter for denne form for specialeeksamen: Den giver mulighed for at efterprøve den studerendes viden og evne til at argumentere, den fremmer mere alsidige kompetencer, og den udgør en mere meningsfuld afslutning af mange års studium en blot det at modtage en karakter med posten. Men når nu specialestudiet kun må tage et halvt år, kan det blive et problem, at der efter afleveringen af rapporten skal gå et par uger, mens censor og eksaminator læser produktet og forbereder eksamen. På Humaniora ved Aalborg Universitet har der på denne baggrund for nyligt været taget initiativ til at indføre mulighed for, at studerende kan fravælge den mundtlige del af specialeeksamen. Det illustrerer, hvordan stramningen af rammerne for specialet kan føre til fravalg af en pædagogisk ønskelig eksamensform.

Et andet eksempel gælder forholdet mellem orlov og færdiggørelsesbonus. Studerende har ret til at tage orlov fra studiet. Mulighederne er godt nok begrænsede: Man skal have bestået første semester på kandidatuddannelsen, og man må ikke have påbegyndt specialet. Orlov indebærer også, at man økonomisk skal klare sig selv: Man kan ikke få SU og heller ikke sociale ydelser. Men muligheden for orlov er der 
dog, og den kan være nyttig. Den kan for eksempel giver lejlighed til at komme lidt til hægterne efter dødsfald i den nærmeste familie eller andre krisesituationer. Eller den kan bruges til, at man i en periode kan koncentrere sig om et erhvervsarbejde, som man måske kan fastholde efter specialet. Orlov er ikke altid velbegrundet, men den kan være nødvendig og relevant for studerende og deres videre karriere.

Man skulle tro, at retten til orlov havde konsekvenser for opgørelsen af færdiggørelsesbonus. Hvis studerende har orlov i nogle måneder (og dermed hverken bruger undervisningsressourcer eller SU), kan det vel ikke tælle med i studietiden. Men det gør det: Videnskabsministeriets krav til universiteternes indberetning af studietider (de såkaldte myndighedskrav) præciserer, at den eneste form for orlov, som ikke tæller med i studietiden, er barselsorlov. Så hvis man som uddannelsesleder eller lærer ved en universitetsuddannelse gerne vil opretholde uddannelsens økonomiske grundlag, må man altså af alle kræfter søge at forhindre studerende i at bruge deres ret til orlov, uanset hvor gode personlige eller faglige grunde de kan have.

\section{Konsekvenser for studerende og lærere}

De gennemførte foranstaltninger til at afkorte studietiderne og de uddannelsespolitiske diskurser, som knytter sig til dem, må påvirke de studerendes forhold til deres uddannelse og studieaktiviteter. De skaber et øget pres for, at de studerende skal udøve strategisk og effektiv planlægning af deres studieadfærd. Det kan lyde rimeligt nok, men reelt er det svært.

Det centrale i den læring, som foregår inden for universitetsstudier, er studerendes selvstændige tilegnelse af evnen til at tilgå og fordybe sig i faglig viden og at bearbejde, supplere og forny denne viden (Bowden \& Marton, 1998). Det er grundlæggende den samme læring, som sker i forskning. Den centrale pointe ved forskningsbaseret undervisning er ikke i sig selv det forhold, at lærerne også er forskere, men at de studerende undervises og arbejder i et læringsmiljø, hvor faglig erkendelse og fordybelse er til stede på mange forskellige måder. I denne forstand er læringen også en socialisering ind i en organiseret faglighed (Rasmussen, 2005). Læring i universitetsstudier bygger på faglig interesse; de studerende må have tilstrækkelig interesse for uddannelsens fag og problemstillinger til at kunne engagere sig i det selvstændige arbejde med faget. For langt de fleste studerende på kandidatuddannelser er denne interesse også til stede efter, at de har valgt fag og gradvis specialiseret sig. Men læringen er en åben proces, hvor man må afprøve forskellige muligheder, og hvor nogle af dem kan vise sig at være vildspor eller at kræve mere arbejde og længere tid, end man havde forudset. En af de studieaktiviteter, hvor dette ofte viser sig, er praksisprojekter, hvor de studerende $i$ en periode medvirker eller undersøger $i$ en sammenhæng uden for universitetet, som de ikke kender på forhånd. En anden er 
internationale studie- eller praktikophold. En tredje er specialeskrivningen. Både for disse aktiviteter og for andre gælder det, at netop det at have afprøvet forskellige muligheder ofte vil styrke det faglige udbytte og dermed kandidaternes kompetence.

Hvis kravet om at planlægge sin studieadfærd strategisk og effektivt bliver for stærkt, kan det betyde, at studerende søger at styre uden om studieaktiviteter, hvor kravene til indsats og tidsanvendelse er mindre forudsigelige. Det underminerer potentielt de særlige kvaliteter, som ligger i den interessebaserede, selvstændige læring.

Men konsekvensen kan også være, at de studerende ikke kan leve op til kravet om planlægning af studieadfærden og dermed marginaliseres. Det gælder nok især studerende med færre ressourcer og begrænset daglig kontakt med studiemiljøet. Jeg har set flere eksempler på specialestuderende, som på grund af manglende overblik og andre omstændigheder - for eksempel et erhvervsarbejde, som de ville kunne fortsætte med efter endt uddannelse - pludselig har brugt deres tredje eksamensforsøg og står i en overhængende risiko for ikke at kunne afslutte deres kandidatuddannelse.

Som nævnt foreligger der, så vidt jeg ved, ikke bredere undersøgelser af konsekvenserne af de rammer for specialet, som blev indført med Velfærdsaftalen af 2006. Der er gennemført en undersøgelse af specialestuderende ved Statskundskab på Københavns Universitet, hvis hovedresultat er, at de fleste studerende er tilfredse med tidsbegrænsningen, og at karakterniveauet ikke er faldet (Jensen \& Jensen 2011). Mine egne erfaringer og informationer fra kolleger peger også på, at aftalen for mange studerende har ført til en mere overkommelig og dermed tilfredsstillende afslutning på uddannelsesforløbet. Men jeg tror også, at en del studerende er blevet sat i unødigt svære situationer og måske har måttet opgive at afslutte uddannelsen.

For universiteternes lærere betyder det politiske fokus på kortere studietider, at de via mål, eksamenskrav, pensum og stofgennemgang skal tilbyde de studerende mest mulig sikkerhed for, at de kan gennemføre til tiden. Det kræver både universiteternes ledelser og de studerende.

Også for lærerne er der en balance, som skal findes. Der bør selvsagt være klare mål og rammer for universiteternes uddannelser, og det er et fremskridt at universiteterne i dag som regel beskriver disse mål og rammer i overskuelig og offentligt tilgængelig form. Men hvis forventningerne om studieforløb til tiden bliver for stærke, risikerer universitetspædagogikken at blive mindre orienteret mod de studerendes selv- 
stændige faglige læring og i stedet mere orienteret mod effektivitet i de studerendes adfærd.

\section{Afslutning}

Uddannelsespolitikken må tage højde for begge de økonomiske logikker, som gælder for de videregående uddannelser, både uddannelsernes bidrag til konkurrenceevne og velstand og uddannelsernes omkostninger på statsbudgettet. Men jeg finder det skræmmende, at både regering og opposition i deres økonomiske planer lægger så stærk vægt på yderligere afkortning af studietiderne uden at overveje eller søge at skaffe sig viden om konsekvenserne af de allerede gennemførte tiltag. Jeg ser det som udtryk for, at diskurserne om de lange studietider har fået lov til at leve deres eget liv i offentligheden og blandt de politiske beslutningstagere.

Jeg mener der er behov for tiltag og argumenter, som peger i en anden retning. Der er brug for analyser og indlæg, som kan fremme en mere alsidig og nuanceret økonomisk forståelse af universitetsuddannelserne. En forståelse, hvor uddannelsernes rolle ikke vurderes ud fra overordnede og naive økonomiske modeller, og hvor de økonomiske vurderinger forbindes med virkelighedens samspil mellem uddannelse, arbejde og konkurrenceevne.

Der er brug for institutionelle og pædagogiske tiltag, som kan bidrage til at opbygge studiemiljøer, der tager hånd om og understøtter studieforløbene. Det er et positivt alternativ til de disciplinerende foranstaltninger, som er indført de senere år, og som rummer stor risiko for utilsigtede virkninger. Der er også brug for praktik- og trainee-ordninger, som kan støtte de studerende i bestræbelserne for at skabe bedre kontakt med arbejdslivet frem gennem uddannelserne. Som led heri må skabes mere fleksible rammer for specialeskrivningen, som kan give de studerende mulighed for $\mathrm{i}$ uddannelsens afsluttende fase at opretholde en forankring i arbejdslivet. Noget af dette kræver ændringer i lovgivningen; men det er først og fremmest universiteternes eget ansvar at styrke studiemiljøerne og broerne til arbejdslivet.

Jeg har i artiklen peget på, at hverken tilsigtede eller utilsigtede virkninger af de senere års politiske initiativer til at nedbringe studietiderne er kendte. Det kunne begrunde et midlertidigt effektiviseringsstop i universitetspolitikken forstået som at træffe beslutning om, at der ikke fra politisk side indføres flere tiltag til afkortelse af studietiderne, før virkningerne af allerede indførte tiltag er kendt.

Palle Rasmussen er professor i uddannelses- og læringsforskning ved Institut for Læring og Filosofi, Aalborg Universitet. Han har forsket $i$ uddannelse og læring inden for forskellige dele af uddannelsessystemet og $i$ arbejdslivet. I forhold til universiteter og videregående uddannelser har han bl.a. arbejdet med uddannelsespolitik, kønsforskelle, evaluering og pædagogik. 


\section{Litteratur}

Bowden, J., \& Marton, F. (1998). The University of Learning. London: Routledge.

Jensen, H. N., \& Jensen, H. (2011) "Specialeskrivning på seks måneder". Dansk Universitetspædagogisk Tidsskrift, nr. 10, 2011, s 25-30.

Junge M., \& Skaksen, J. R. (2010). Produktivitet og videregående uddannelse. København: DEA.

Lundvall, B. (2001). "Universitetet i den lærende økonomi", in Maskell, P., \& Jensen, H. S. (red.) Universiteter for fremtiden - universiteterne og videnssamfundet. København: Rektorkollegiet.

Ministeriet for Videnskab, Teknologi og Udvikling (2005). Hovedresultater fra undersøgelsen om de studerendes erhvervsarbejde - og sammenhangen med frafald, studietid, startløn og beskæftigelse.

Pedersen, O. K. (2011). Konkurrencestaten. København: Hans Reitzel.

Rasmussen, P. (2005). "Læringens samfundsmæssighed", in Hermansen, M. (red.), Læring - en status. Århus: Klim.

Regeringen (2010). Danmark 2020. København: Statsministeriet.

Regeringen (2010a). SU, der skaber vækst og beskxftigelse. København: Undervisningsministeriet.

Socialdemokratiet \& SF (2010). En fair løsning - sammen ud af krisen.

Socialdemokratiet \& SF (2010). Fair løsning 2020 - sammen om Danmark.

Undervisnings- og Bygningsstyrelsen (2011). Notat om universiteternes bachelor- og kandidatuddannelser. 